6 | 2012

Revisiting Space and Place: South Asian Migrations in Perspective

\title{
Introduction. Places on the Move: South Asian Migrations through a Spatial Lens
}

Tristan Bruslé and Aurélie Varrel

\section{(2) OpenEdition}

\section{Journals}

Electronic version

URL: http://journals.openedition.org/samaj/3439

DOI: $10.4000 /$ samaj.3439

ISSN: $1960-6060$

Publisher

Association pour la recherche sur l'Asie du Sud (ARAS)

Electronic reference

Tristan Bruslé and Aurélie Varrel, «Introduction. Places on the Move: South Asian Migrations through a Spatial Lens », South Asia Multidisciplinary Academic Journal [Online], 6 | 2012, Online since 28 December 2012, connection on 02 May 2019. URL : http://journals.openedition.org/samaj/3439 DOI : 10.4000/samaj.3439

This text was automatically generated on 2 May 2019.

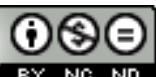

This work is licensed under a Creative Commons Attribution-NonCommercial-NoDerivatives 4.0 International License. 


\title{
Introduction. Places on the Move: South Asian Migrations through a Spatial Lens
}

\author{
Tristan Bruslé and Aurélie Varrel
}

1 This SAMAJ special issue sets out to highlight a geographical perspective about South Asian migrations in the wake of 'the spatial turn' that has occurred in social science (Soja 1989). ${ }^{1}$ In a world where movements of all types have intensified, geography has not been eliminated (Soja 2009): on the contrary globalization 'has accentuated the significance of location' (Warf and Arias 2009) with places now symbols of the heterogeneization of the world (Appadurai 1996). Diasporas take root in places, and places are landmarks on migration routes. We put forward the premise that migration and migrants change space and create places that reflect where people come from, how they have migrated and what their relation to the host society is. At the crossroads between individual agency, collective imagination and global migration, space is this issue's point of entry into analyzing migration. We envision migration as a social phenomenon that sets distant places in relation to each other, thus creating specific relational spaces.

2 Space is a difficult concept to grasp, full of abstractions (Creswell 2008) and increasingly understood in conjunction with power and knowledge (Lefebvre 1999 among others). Space will be considered as 'one of the dimensions of the society that corresponds to relationships established through distance between diverse realities' (Lévy \& Lussault 2003: 325). Henri Lefebvre (1974) stresses space's mental and material dimensions and the fact that space is an instrument of domination. As Tim Creswell (2008) puts it, following John Agnew (1987), space can be seen as embracing a network of places, which are a combination of a location (the answer to the question 'where?'), a locale (the material setting) and a sense of place (subjective and emotional attachment to place). Place is often considered to be the equivalent of the French word lieu, defined by Lévy and Lussault (2003) as the smallest geographical unit where distance is abolished so that co-presence is the main feature of a lieu. Place is therefore where social relations take place and where spatial meanings are created. In this issue, we also seek to stress the fact that migrations 
encompass different scales, from a global scale corresponding to the dispersion of migrants across countries and towns, to a more intimate one, e.g. the house or the room.

Although it is commonplace in migration studies to note that places (houses, religious buildings, restaurants, community centres, etc.) are (re)created so that migrants feel at home when away from their native place, this issue has barely been addressed as far as South Asian spaces 'on the move' (Rigg 2007) are concerned, and this will be furthered develop below. This oversight in the literature has also been highlighted recently by Carol Upadhya and Mario Rutten (2012), although their scale of interest is situated at the mesoscale, focusing on small regions. Here we propose to adopt an approach to the study of migrants' places (temples, dwelling places) through the migration lens: not places per se, whether inside or outside South Asia, but places as loci in broader, transborder, multilocal and transscalar migratory spaces. We argue that analyzing the materiality of place-making by migrants-how and where places are designed, built, organized, funded, made visible or not to the public at large-adds a new, rich dimension to our understanding of South Asian migrations.

The four contributions deal with different South Asian communities (Sikhs, Nepalese, Tamil diasporans and Indian returnees) scattered over Europe, Northern America, the Middle-East, the Indian Ocean and India.

\section{Why space and place?}

5 This concern stems from our shared geographical background and interest in mobility within and from South Asia. Edward Soja rightly points out that: 'As spatial thinking began to flourish outside geography, most geographers remained relatively unaware or indifferent' (2009: 24). Indeed, the use of the terms 'space' and 'place' in social science, as well as the use of a geographical idiom (e.g. 'to locate', 'to map') has taken on enormous proportions since Soja spoke about the spatial turn in the mid-nineties. It is particularly evident in Anglo-Saxon academic circles, to which most scholars working on South Asia belong. Influenced by the work of Henri Lefebvre and Michel Foucault, Marxist geographers, especially David Harvey, contributed to propagating spatial concepts. As a result, the use of space and place as categories has spread far beyond the limited field of geography, thus considerably enriching the debate in social science and the humanities (Warf \& Arias 2009). However, it turns out that space and place are often mutually interchangeable and are used indiscriminately to merely restore position and context in the analysis of social phenomena. These analytical categories are used by many social science scholars in a somewhat restricted manner. In response to the call for papers for this issue, we received abstracts proposing situated case studies or addressing space in a vague, if not metaphorical manner. This inspired us in turn, as geographers, to suggest broadening the scope to other ways of using the analytical categories of space and place, with regard to the study of South Asian migrations.

\section{Space and place in migration studies}

On the whole, the field of migration studies has not succumbed to space blindness. Over the last two decades it has been considerably reshaped by burgeoning new approaches that Blunt (2007) has separated into three different categories: diaspora studies, the 
'transnational turn' (Levitt \& Nyberg-Sørensen 2004) and the 'mobility turn' (Sheller \& Urry 2006; Hannam et al. 2006: 1). It is worthwhile noting that these approaches are not only extremely similar but overlap with each other (Anteby-Yemini \& Berthomière 2005:13-15; Blunt 2007). ${ }^{2}$

7 The literature on South Asian migrations has tended to enthusiastically adopt the approach of diasporic studies, without much critical distance in many cases. In a sense, it reflects the recent discovery of their diasporas by South Asian governments and audiences in the 2000s (Carsignol 2011; Therwath 2011). The study of the mobility and migration of people of South Asian origin has focused on processes of migration on the one hand and integration issues in distinct host communities on the other (Rajan et al. 2010). However, space and place have not been central notions in the study of South Asian diasporas, even in recent major works (Raghuram et al. 2008; Kalra 2009; Kibria 2011). This is partly accounted for by the strong presence of disciplines such as economics, demography, history and political science in research conducted on South Asia. It is predominantly in French academic circles that spatial organization has been put forward as one of the main features of diasporas, emphasizing the diasporas' multipolarity and interpolarity, geographical dispersal as a resource (Ma Mung 2004), and developing the conception of diasporas as relational spaces comprising communities scattered over different countries and yet united by a shared reference to a (sometimes imagined) homeland (Bruneau 2004, Ma Mung 2004). This partly explains our interest in this diaspora studies approach, which converges with the transnational approach, as identified by Blunt (2007).

8 The transnational approach has prompted us to draw attention to 'the processes by which immigrants forge and sustain multi-stranded social relations that interlink their societies of origin and settlement' (Basch et al. 1994: 6). It has subsequently insisted on simultaneity, long-distance practices and the reconfigurations of culture (Levitt 2010), which are all new fields of investigation developed by proponents of the transnational approach. As they have been largely influenced by the spatial turn itself, they have benefited from the surge in references to the space/place/scale triad. Yet scholars committed to the transnational approach have largely considered space and place as the backdrop to what they observe, even when intending to pay closer attention to these categories. The introductions to two major books on transnational spaces provide clues as to how space is conceived and is to be addressed: 'transnationality is a geographical term, centrally concerned with reconfiguration in relation with place, landscape and place' (Crang et al. 2004: 4, our emphasis). Similarly, their understanding of space may be immaterial: 'social relations are not framed in a given (container) space, but constitute space' (Pries 2001:16). Our intention is to switch the lens to the reconfiguration of place, landscape and space by transnational flows, hence to how migrations influence the processes of spaceand place-making, sometimes altering landscapes, but sometimes in a less obvious manner.

\section{Geography strikes back}

Geography has developed the tools to grasp the complexity of the interactions between space and mobility/migration processes (King 2011). Following on from Lefebvre (1974), it has been a common belief that space is a social construct. It is particularly the case in the context of accelerated movements of people that make encounters between different 
populations inevitable and creative. The sentimental attachment to place, as described in humanistic geography (Tuan 1990 for example), lays emphasis on place as a security, a cocoon where human feels rooted. Yet it is an individual and psychological way of understanding human relationships with the social and physical world, which would deny social and dynamic components within relations to places. David Harvey (1989) and Doreen Massey (1993) rightly warn against such essentializing of place and space. The 'progressive sense of place' as developed by Massey (1993) argues that places support group and family identities, but that these identities should not be considered as unique or bounded or rooted in history. The dynamics of places, built by social interactions, means that they are never fixed and have several dimensions, depending on the scale of observation: 'the specificity of place also derives from the fact that each place is the focus of a distinct mixture of wider and more local social relations' (Massey 1993: 68). The fact that places are assigned multiple identities by different social groups can either be a source of cultural richness or a source of friction. Indeed, because place is a process happening at the conjunction of different groups' interests, it is prone to conflict (Creswell 2008, Lefebvre 1974, Massey 1993); it is permanently reshaped and reorganized in the flow of space and time (Harvey 1996).

When talking about transnational social spaces (Pries 1999), transnational social fields (Basch et al. 1994), or migratory space (Simon 2008), we underline the fact that migration is a spatial phenomenon in that migrants live their lives in several places in several countries. Space is a continuum where life trajectories and individual, as well as collective strategies, literally take place in the sense that people's lives, along with the circulation of ideas and artifacts, contribute to modifying or to creating places and migratory spaces. Movement is inherent to place-making.

11 Indeed, in a context of mobility, new forms of relationships to space are created. Migration patterns tend to become embedded in people's lives to such an extent that multilocality is part of their 'normal' life. Tamil officiating priests circulating in the diasporic space on various work contracts is one such example of religious-induced mobility (see Trouillet in this issue). Another example of this approach in reference to migrations from South Asia was developed by Voigt-Graf (2004), who analyzed the transnational spaces of three different communities (Fijians, Punjabis, Kannadigas) that had settled in Australia. The author accurately describes how the identity of these migrants of South Asian origin was based on references to multiple countries where these people had roots or life experiences, in subtle constructions that differed for each group, thus creating distinct migratory spaces. In order to understand the actors' logics and strategies, one has to envisage migrants' daily lives within a web of places that may be scattered over several continents. They do not belong only to where they are but are part of broader global networks of social and spatial relations. This conception of places as part of networks fits in with Massey's interpretation (1993), whereby she insists on viewing places as extraverted, that is as 'including a consciousness of [their] links with the wider world, which in a positive way integrates the global and the local' (Massey 1993:66). It also corresponds to the 'mobility turn' introduced by Sheller and Urry: 'the mobilities' paradigm indeed emphasizes all places are tied into at least thin networks of connections that stretch beyond each such place and mean that nowhere can be an "island" (Sheller and Urry 2006: 209). Hence migrants' places cannot be considered only in relation to their immediate social, economic environment but take their real sense in the 
global web of relations linking scattered communities. They are ever changing locales due to ever changing social interactions, perceptions, etc.

Everyday life places of migrants can no longer be considered as isolated places but belong to a global space of living that transcends national borders and are part of broader social networks; this is the very premise shared by all contributions to this special issue. We agree with the idea of 'translocal geographies' developed by Katherine Brickell and Ayona Datta (2011:4): 'a simultaneous situatedness across different locales which provide ways of understanding the overlapping place-time(s) in migrants' everyday lives'. This emphasis on everyday practices and geographical locales appears to be central to taking the transnational paradigm further, as David Conradson and Adam Latham (2005: 228-9) put it: 'an investigation of life worlds of these mobile individuals and the activities which constitute them, provide a useful counterpoint to the inflationary tendencies of some writings on globalization'. With time, through everyday practices, the newly created locations become meaningful to their inhabitants and become places (Creswell 2008, Rigg 2007).

We therefore intend to show that even if place manifests long, epitomized group fixity or sedentarity, the place of roots (Creswell 2008), there is no contradiction between place and migration along fluid and moving lines: places are parts of routes or routes themselves. In the context of mobility that has become all-encompassing, places are built by individuals and groups who move or have moved beyond any allegedly ancestral space of living. The social construction of place is thus not restricted to locales where roots are deep but, in particular in the case of international migrants or diasporans, place is part of a process of relocalization, or of multi-localization (Ma Mung 2004).

South Asian places, as described in this issue, are undeniably the result of both ancient and recent global interconnections, of population and capital mobility. In this sense, our interest lies not only in the creation of localized places but in the creation of networks of places, whether they are called 'transnational' or 'migratory' spaces.

\section{The city as a privileged place of observation}

While reviewing the literature on South Asian migration, we were confronted with the paucity of studies adopting a spatial perspective.

A notable exception are the case studies of migrants in urban settings, which probably owes much to the Chicago School of sociology, which paved the way in the fields of migration and urban studies (King 2011). In addition, the city has made a strong comeback in transnational studies over the last decade, starting with the inspiring work of Michael Peter Smith (2001) on 'transnational urbanism' that has given new impetus to the study of cities through a migration lens, while departing from the bias of methodological nationalism, that is, to an analysis restricted to the scale of the NationState (Glick-Schiller \& Caglar 2011) This has been taken further in a 'second wave of transnational research' (Rogers 2005: 403) and has fostered an interest in the 'everyday' (Conradson \& Latham 2005) and in micro-scales of analysis. Nevertheless, there are few spatialized and geographical publications on South Asian migrant communities, although the aforementioned recent developments in migration studies have lent importance to the urban realm. Generally speaking, most contributions address ethnic areas, which are very understandably located for the most part in the United Kingdom (among others: 
Alexander 2011; Ballard 1994; Werbner 2005), ${ }^{3}$ but also in imperial diaspora 'hotspots', such as 'little India' in Kuala Lumpur (Leclerc 2012), or in new key locations such as Dallas in Texas (Bretell 2005), La Chapelle and the 'quartier indien' in Paris (Chatterji 2007; Goreau-Ponceaud 2009).

In this respect, it is not coincidental that all the articles in this issue deal to some extent with the urban dimension, even though the one by Tristan Brusle describes an 'antiurban' space, illustrated by the case of Qatar labour camps where Nepalese migrants are housed. Acquiring an in-depth understanding of the complexity of contemporary transnational flows is at stake here. In the eloquent introduction to their book on Translocal geographies, Brickell and Datta prompt us to consider 'cities as sites of translocality par excellence, harbouring places of origin, settlement, resettlement and transit. Situated within the intersections between place and displacement, location and mobility, settlement and return, cities are critical to the construction of migrant landscapes and the ways in which they reflect and influence migratory movements, politics, identities and narratives' (Brickell \& Datta 2011: 16). In this volume, Ester Gallo explores the construction of religious places in Italian cities, which reflect how Sikh migrants make places for themselves in the local urban fabric, contrasting two periods and two different settings, in Roma and in a small town which offer very different conditions of settlement for the establishment of gurdwaras.

In this volume, we try also to include what is going on in South Asia itself, namely in South Indian cities. Using the diaspora as a point of entry, the programme of research on 'Diaspora and the city' conducted in Calcutta by Alison Blunt, Jayani Bonnerjee and Noah Hysler-Rubin (2012) focuses on arguing for a need to examine all kinds of traces left by international migrations in South Asian cities, through a meaningful exploration of the geographies of memories, nostalgia and return visits of Chinese, Jewish and Anglo-Indian migrants to Calcutta. By developing the idea of Calcutta as a diaspora city, this project builds a strong case for considering cities as relevant scales in the study of transnational spaces: 'thinking in terms of a diaspora city reveals the way in which cities are already diasporic, shaped by multiple migrations that unsettle ideas about ethnicity, origin and a nation as homeland' (Blunt et al. 2012: 2). The contribution by Pierre-Yves Trouillet provides an insightful example of such dynamics, as the last case study in his article presents a Hindu temple in Chennai that was built by migrants and that includes a replica of another temple located in the USA. Aurélie Varrel describes in careful detail the process of creation of a new neighbourhood in Bangalore through elite migrants' transnational practices. This case study asserts that the making of local places has to be considered as a combination of global actors' strategies, of the State and of local economic and political entrepreneurs. It also supports the consideration developed by Brickell and Datta (2011:17) who highlight the need to switch scales in order to focus on neighbourhoods, urban landscapes and architecture though the migration lens. Although this may seem obvious, it has so far rarely been done in South Asian cities, with the exception of the aforementioned programme 'Diaspora and the city' (Blunt et al. 2012).

\section{Migrants' construction of their own places: from public to private places}

The focus on space and on the different scales encompassed by migrations leads us to address public as well private places. Humans are not equal before space. Lefebvre clearly 
distinguishes, through a political vision of space, the different qualities of space. The space of the elite, of the architect or of urban planners is the dominant one. In this already framed space, individuals, through their spatial everyday practices and strategies (de Certeau 1980) appropriate it. This lived space is the space of everyday life where social reproduction occurs: it is the dominated space. Hence space is anything but neutral. The abstract space described by Lefebvre, that is the dominant one, rules the lives of the common people, who are meant to be 'silent users', who are deprived of the capacity to resist and act (Lefebvre 1999: 63). This is particularly the case of migrants, who are not often in a position to be public space-makers (see Bruslé in this issue). As Katherine Brickell and Ayona Datta (2011:17) put it: 'migrants' everyday lives are negotiated and experienced not just at the level of the city but also within specific urban sites-in its workplaces, homes and a range of buildings, streets and neighbourhoods where divergent and often conflicting formations of the local are produced'. This quotation includes different types of places that are built or appropriated by migrants; space becomes place when given meaning, values and names (Creswell 2008). And for researchers, places constitute an entry point into migrants' worlds.

Places, such as they are considered here, are eminently social: they are created by and produce social interactions, and in that sense can be considered as resources. Aurélie Varrel describes homes built by NRIs as financial and prestige resources; Ester Gallo and Pierre-Yves Trouillet analyze temples as bases where migrants/diasporans can reactivate their belonging to a community. Identity dimensions are omnipresent in the two articles that focus on gurdwaras (Gallo) and temples (Trouillet). They provide examples of newly created landmarks that are more or less visible to local societies and thus reflect differences in the diaspora' self-assertion. The temple as a 'haut lieu' (Trouillet) publicly asserts the Hindu community in Mauritius: it is a place of distinction, gathering and belonging. The religious place also serves the political objectives of certain communities, such as resisting Bhojpuri domination. And lastly, Trouillet's study shows how these places are inserted in the life worlds of migrants and in transnational complex flows of ideas, persons, things and money. The migration space takes shape in circulations and in localized places. Gallo's study of Sikh gurdwaras in Rome and Terni also shows that public assertion of otherness through the materiality of places is the object of negotiations within the community and with the authorities. By shaking off the imposed invisibility of warehouse-like places of worship and embracing the welcome, official visibility symbolized by the temple in the very centre of Terni, Sikhs have at last been able to achieve public recognition. In Tamil and Sikh cases, issues of public visibility and of respectability are consciously discussed and viewed as a matter of political commitment to the country in which they have settled.

21 Public spaces are more prone to conflicts between groups, particularly within the European context of an increase in xenophobia, the issues of visibility of a mosque or of a temple being the symptom of broader issues of group integration and representation. The picture that illustrates this special issue represents these problems: in the heart of Paris' La Chapelle neighbourhood, a labile religious space is emerging. On the day of the Ganesh festival, a Hindu procession takes place. This is the only day in the year when Hinduism is visible in the public space (Goreau Ponceaud 2009), in Paris' only 'hotspot' of South Asian ethnic business. This very well organized event is authorized and supported by the municipality, yet it is a risky business: it is a religious event in a country where such events are hardly tolerated in the public space and it is staged by the Sri Lankan Tamil 
community that does not hesitate to take to the streets to protest against the situation in North Sri Lanka. During these rallies, tension often runs high (Dequirez 2010). However, it is still a momentary manifestation of the presence of an immigrant community. In comparison, Trouillet's case-study about Hindu temples in Mauritius leads us to think that place-making must be observed diachronically: in this case, the more settled the community, the more politically integrated it is, and the more salient its presence in the landscape. Place-making in the host society's public space certainly requires a political voice and negotiation skills that, as Gallo remarks, are inaccessible to illegal migrants. For it to become institutionalized, the diaspora as a social form needs the materiality of places that contribute to its existence, for the sake of its own members (Gallo).

This issue contains only one article on private places, the one by Tristan Bruslé, which appear to be a rarely addressed and difficult topic. Private spaces, as studied by ToliaKelly (2004), however, might enable us to understand how places are rebuilt, how memories and a homeward orientation are established in order to create a hybrid atmosphere, between here and there. Thus, spatial strategies need to be carefully observed in order to decipher how a new culture emerges and how adaptations to constraints are handled. Bruslé reports that even in a situation of extreme deprivation of any means to act upon space, migrants find ways to create basic places, thus creating a kind of intimacy and soft resistance in high-density labour camps. Here space acts as a refuge but without the identity component it usually entails.

All these articles, however, deal with the materiality of places that have architectural dimensions. In Trouillet's contribution, the materiality of Tamil temples and the transnational character they take on from the very beginning of their construction reminds us that a diaspora needs places, that it is to say not an ethereal social form: religious places help a community to establish itself vertically (in the Mauritian or Canadian national territory) and horizontally (in the diaspora space). Aurélie Varrel reminds us that places can also be considered firstly as purely economic goods. The house, bought by the migrant 'who made it abroad' or the returnee, may be a question of prestige thanks to its architecture, yet it is also an investment carefully selected for its financial worth.

\section{Assigning value to places}

24 The study of spaces inhabited by people who move or by the descendants of emigrants enables us to contribute to the debates on integration, place-making, transnational spaces and the dialectics of scale. Besides their materiality, places are loci of interaction, innovation and negotiation, which are constructed by people who live far from their place of birth. In this context, places inhabited by people on the move also help us to understand the migrant community itself and its relationship with the social, political or natural environment where they live, either on a temporary or permanent basis. Contributions by Gallo, Trouillet and Bruslé deal with these issues. 'Migrant's relational approach' (Gallo) to places is studied through individual histories but with attention to the entire group's degree of integration. Places have meanings and values for a group or an individual only if contextualized in the group/individual biography. In the case of gurdwara in Rome and Terni (Gallo), they do not represent diasporic feelings for newly arrived migrants who discover only exploitation and submission in these places. It is only for fully integrated migrants that these temples are associated with a global belonging. ${ }^{4}$ 
In the case of Nepalese labour camps, the camps are not associated with any high values except for a handful of men who have managed to secure a good position in the company. Otherwise, the camp is a place of 'last resort' devoid of any attachment or pride.

We have opted to draw attention to the values attached to spaces and to differences in place-making practices. Places do not embody the same values for all those who frequent them: depending on their social class, individual aspirations, the position of the group within the host society, the values attached to places vary greatly. Varrel presents the long-distance strategies of investment in housing in India, which are deployed by affluent migrants and are strongly determined by their upper class sense of belonging, tastes and cultural capital. At the other end of the social ladder, Bruslé describes practices of spatial relegation and feelings of exclusion and contempt, experienced by low-skilled Nepalese migrants in Qatar in a heavily gendered setting, the labour camp, which is a strictly masculine space. These two articles also show how the power over space is differential. The capacity to control space and leave footprints in it depends to a large extent on the social group's economic and cultural capital. Some build a house or a temple, while others succeed in arranging a private space of their own with the little means available. Like for other issues, class belonging is indeed of consequence in place making. And lastly, one might say that the value of the different places studied in this issue also depends on what people are able to achieve in these places or on the achievements they symbolize. Whether useful for finding a job, associated with survival, with enrichment or with prestige, places are undeniably linked to what migrants project upon them and expect from their own presence there.

\section{BIBLIOGRAPHY}

Agnew, John A. (1987) Place and Politics: The Geographical Mediation of State and Society, Winchester: Allen and Unwin.

Alexander, Clare (2011) 'Making Bengali Brick Lane: Claiming and Contesting Space in East London', The British Journal of Sociology, 63(2), pp. 201-20.

Anteby-Yemini, Lisa; Berthomière, William; Sheffer, Gabriel (eds.) (2005) Les diasporas: 2000 ans d'histoire, Rennes: Presses Universitaires de Rennes.

Appadurai, Arjun (1996) Modernity at Large: Cultural Dimensions of Globalization, Minneapolis: University of Minnesota Press.

Ballard, Roger (1994) Desh Pardesh: the South Asian Presence in Britain, London: Hurst.

Basch, Linda; Glick-Schiller, Nina; Szanton Blanc, Christina (1994) Nations Unbound: Transnational Projects, Post-colonial Predicaments and De-territorialized Nation-States, Langhorne: Gordon and Breach.

Blunt, Alison (2007), 'Cultural Geographies of Migration: Mobility, Transnationality and Diaspora', Progress in Human Geography, 31(5), pp. 684-694. 
Blunt, Alison; Bonnerjee, Jayani; Hysler-Rubin, Noah; Lahiri, Shompa (2012) South Asian Diaspora, Special Issue: 'South Asian Cities and Diaspora', 4(1), pp. 1-4.

Brettell, Caroline (2005) 'The Spatial, Social, and Political Incorporation of Asian Indian Immigrants in Dallas', Urban Anthropology, 34, pp. 247-80.

Brickell Katherine; Datta, Ayona (eds.) (2011) Translocal geographies: Spaces, places, connections, London: Ashgate.

Bruneau, Michel (2004) Diasporas et espaces transnationaux, Paris: Economica.

Carsignol, Anouck (2011) L'Inde et sa diaspora: Influences et intérêts croisés à l'île Maurice et au Canada, Paris: Presses Universitaires de France.

Certeau (de), Michel (1980) L'invention du quotidien: 1. Arts de faire, Paris: Gallimard.

Chatterji, Miniya (2007) 'Redefining Boundaries? The Case of South Asian Muslims in Paris' quartier indien', SAMAJ (South Asia Multidisciplinary Academic Journal), 1, http:// samaj.revues.org/119.

Conradson, David; Latham, Adam (2005) 'Transnational Urbanism: Attending to Everyday Practices and Mobilities', Journal of Ethnic and Migration Studies, 31(2), pp. 227-33.

Crang, Philip; Dwyer, Claire; Jackson, Peter (eds.) (2004) Transnational Spaces, London: Routledge. Creswell, Tim (2008), Place: A Short Introduction, Malden: Blackwell Publishing.

Dequirez, Gaelle (2010) 'Processus d'appropriation et luttes de représentation dans le 'Little Jaffna' parisien', Revue européenne des migrations internationales, 26(2), pp. 95-116.

Glick-Schiller, Nina; Caglar, Ayse (eds.) (2011) Locating Migration: Rescaling Cities and Migrants, Ithaca (New York): Cornell University Press.

Goreau-Ponceaud, Anthony (2009) 'La chapelle : un théâtre monde’, E-Migrinter, 4, pp. 58-69

Hannam, Kevin; Sheller, Mimi; Urry, John (2006) 'Editorial: Mobilities, Immobilities and Moorings', Mobilities, 1(1), pp. 1-22.

Harvey, David (1996) Justice, Nature and the Geography of Difference, Cambridge: Blackwell.

Harvey, David (1989) The Condition of Postmodernity: An Inquiry into the Origins of Cultural Change, Oxford: Blackwell.

Kalra, Virinder S. (2009) Pakistani Diasporas: Culture, Conflict and Change, Karachi: Oxford University Press.

Kibria, Nazli (2011) Muslims in Motion: Islam and National Identity in the Bangladeshi Diaspora, New Brunswick (New Jersey): Rutgers University Press.

King, Russell (2011) 'Geography and Migration Studies: Retrospect and Prospect', Population, Space and Place, 18, pp. 134-153.

Koshy, Susan; Radhakrishnan, R. (2008) Transnational South Asians: The Making of a NeoDiaspora, New Delhi: Oxford University Press.

Leclerc, Eric (2012) ‘Brickfields (Kuala Lumpur) : une ancienne enclave ethnique pour les nouvelles stratégies trans-étatiques des informaticiens indiens, E-Migrinter, pp. 87-103.

Leclerc, Eric (2011) International \& Transnational Political Actors: Case Studies from the Indian Diaspora, New Delhi: Manohar.

Lefebvre, Henri (1999) La production de l'espace, Paris: Anthropos, [1974]. 
Levitt, Peggy (2010) ‘Taking Culture Seriously: The Unexplored Nexus Between Migration, Development, and Incorporation', Revue Européenne de Migrations Internationales, 26(2), pp. 139-153.

Levitt, Peggy; Nyberg-Sørensen, Ninna (2004) The Transnational Turn in Migration Studies, Geneva: Global Commission on International Migration, Working paper 6.

Lévy, Jacques; Lussault, Michel (2003) ‘Espace’, in Jacques Lévy; Michel Lussault (eds.), Dictionnaire de la géographie et de l'espace des sociétés, Paris: Belin, pp. 325-333.

Lévy, Jacques; Lussault, Michel (2003) 'Lieu', in Jacques Lévy; Michel Lussault (eds.), Dictionnaire de la géographie et de l'espace des sociétés, Paris: Belin, pp. 560-561.

Ma Mung, Emmanuel K. (2004) 'Dispersal as a Resource', Diaspora: A Journal of Transnational Studies, 13(2/3), pp. 211-225 [1999].

Massey, Doreen (1993) 'Power-geometry and a Progressive Sense of Place', in Jon Bird, Barry Curtis, Tim Putnam, George Robertson and Lisa Tickner (eds.), Mapping the Futures: Local Cultures, Global Change, London \& New York: Routledge, pp. 59-69.

Mohammad-Arif, Aminah; Moliner Christine (2007) 'Introduction. Migration and Constructions of the Other: Inter-Communal Relationships amongst South Asian Diasporas', SAMAJ (South Asia Multidisciplinary Academic), 1, http://samaj.revues.org/136

Pries, Ludger (eds.) (2001) New Transnational Social Spaces, London: Routledge.

Pries, Ludger (eds.) (1999) Migration and Transnational Social Spaces, Aldershot: Ashgate.

Rigg, Jonathan (2007) An Everyday Geography of the Global South, New York: Routledge.

Raghuram, Parvati; Sahoo, Ajaya Kumar (2008) ‘Thinking "Indian Diaspora" for Our Times’, in Parvati Raghuram, Ajaya Kumar Sahoo, Brij Maharaj, Dave Sangha (eds.), Tracing an Indian Diaspora: Contexts, Memories, Representations, New Delhi: Sage, pp. 1-20.

Rajan, Irudaya S.; Varrel, Aurélie; Percot, Marie (2010) 'Introduction' in Irudaya S. Rajan \& Marie Percot (eds.), Dynamics of Indian Emigration: Historical and current Perspectives, New Delhi: Routledge, pp. 1-19.

Rogers, Alisdair (2005) 'Observations on Transnational Urbanism', Journal of Ethnic and Migration Studies, 31(2), pp. $403-407$

Safran, William; Sahoo, Ajaya Kumar; Lal, Brij V. (2009) Transnational Migrations: The Indian Diaspora, New Delhi: Routledge.

Sheller, Mimi; Urry, John (2006) ‘The New Mobilities' Paradigm', Environment and Planning A, 38, pp. 207-226.

Simon, Gildas (2008) La planète migratoire dans la mondialisation, Paris: Armand Colin.

Smith, Michael Peter (2001) Transnational Urbanism: Locating Globalization, Oxford: Blackwell.

Soja, Edward (2009) ‘Taking Space Personally’ in Barney Warf \& Santa Arias (eds.), The Spatial Turn: Interdisciplinary Perspectives, London \& New York: Routledge.

Soja, Edward (1989) Post Modern Geographies: the Reassertion of Space in Critical Social Theory, London \& New York: Verso.

Therwath, Ingrid (2011) 'The Indian State and the Diaspora: Towards a New Political Model', in Eric Leclerc (ed.), International and Transnational Political Actors: Case Studies from the Indian Diaspora , New Delhi: Manohar, pp. 45-63. 
Tolia-Kelly, Divya P. (2004), 'Materializing Post-colonial Geographies: Examining the Textural Landscape of Migration in the South Asian Home', Geoforum, 35, pp. 675-88.

Tuan, Yi-Fu (1990) Topophilia: A Study of Environmental Perception, Attitudes, and Values, New York: Columbia University Press.

Upadhya, Carol; Rutten, Mario (2012) 'Migration, Transnational Flows and Development in India', Economic and Political Weekly, 47(19), pp. 54-62.

Voigt-Graf Carmen (2004) 'Towards a Geography of Transnational Spaces: Indian Transnational Communities in Australia', Global Networks, 4(1), pp. 25-49.

Warf, Barney; Arias, Santa (eds.) (2009) The Spatial Turn: Interdisciplinary Perspectives, London \& New York: Routledge.

Werbner, Pnina (2005) 'Pakistani Migration and Diaspora Religious Politics in a Global Age', in Melvin Ember, Carol R. Ember \& Ian Skoggard (eds.) Encyclopedia of Diasporas: Immigrant and Refugee Cultures around the World, New York: Kluwer Academic-Plenum, pp. 476-86.

\section{NOTES}

1. The editors are grateful to Bernadette Sellers (CNRS, Centre d'Etudes Himalayennes) for her English proof reading work on all the articles gathered in this volume of SAMAJ.

2. Some recent publications on Indian international migrations have even conflated both approaches, by establishing a continuum between them (Koshy \& Radhakrishnan 2008; Safran et al. 2009; Leclerc 2011).

3. It is no coincidence that the United Kingdom hosts the biggest concentration of populations of various South Asian origins and at the same time is a country where geography occupies a dominant academic position.

4. As for the positionality of South Asian groups in migration, it has already been explored in a previous issue of SAMAJ edited by Aminah Mohammad-Arif and Christine Moliner (2007).

INDEX

Keywords: space, place, South Asian diasporas, international migration, city

\section{AUTHORS}

\section{TRISTAN BRUSLÉ}

Research fellow, Centre d'Etudes Himalayennes, Villejuif

\section{AURÉLIE VARREL}

Research fellow, CNRS, Centre d'Etudes de l'Inde et de l'Asie du Sud, Paris 